\title{
Restrictive Measures on Rice Trade in ASEAN: Problems and Solutions
}

\author{
Haniff Ahamat $^{1}$ and Milyan Risydan Al Anshori ${ }^{2}$ \\ \{haniff@ukm.edu.my ${ }^{1}$, milyansay@gmail.com ${ }^{2}$ \} \\ ${ }^{1}$ Faculty of Law, the National University of Malaysia (UKM), 43600, UKM Bangi, \\ Selangor, Malaysia \\ ${ }^{2}$ Faculty of Law, Universitas 17 Augustus 1945 Semarang (UNTAG Semarang), Jl. Pawiyatan Luhur \\ Bendan Dhuwur Semarang, Indonesia
}

\begin{abstract}
The existence of market restrictive measures in rice trade (including the establishment of monopolies) has long been shown to exist in the history of many ASEAN countries. In modern times, Governments allude to food security to rationalize those measures, but the way they are designed and implemented may create new problems rather than solving the existing problems. Based on such a premise, this paper will examine what selected the ASEAN Member States adopts law and policy measures in dealing with rice trade. This paper will also analyze the vulnerability of those measures to market restrictive practices. This paper mainly involves doctrinal legal research with limited use of statistical analysis. This paper will contribute to a balanced rice trade policy in ASEAN.
\end{abstract}

Keyword:restrictive measure, rice trade, ASEAN

\section{Introduction}

Rice trade is significant to the Southeast Asian (SEA) region. The region has a long history of such trade following the introduction of rice to the region by the Austronesians plantation thousand years ago. Rice was one of the leading products traded in SEA entrepots including Jambi, Srivijaya, Melaka, Ayutthaya, and Aceh; where rice from Java Island and Siam were not only sold to foreign traders but also sold and consumed locally in those entrepots. In modern times, SEA contributed (in 2010) to $49 \%$ of the world's total rice exports and (also in 2010) $14.52 \%$ of the world's total rice imports[1]. This makes SEA one of rice baskets of the world.

Restrictive measures are not alien to rice trade. Such measures are not new. Historical accounts have shown that saudagar Raja (Royal merchants) kept a monopoly over rice trade in the ancient Malay Kingdoms and Sultanates, allowing peasants to cultivate rice just for their consumption[2]. In modern times, many ASEAN Member States (AMS) have imposed restrictive measures with respect to including imposition of high preferential tariff rates (Philippines at $30 \%$, Indonesia at $25 \%$ and Malaysia at 20\%), maintaining rice-importing licensing system (e.g. Indonesia), requiring imports to be through a State-owned monopoly (e.g. Malaysia), and implementation of export restrictions favoring big players (e.g. Vietnam)[1]. The main reasons for these measures are that rice is a strategic product, that they are there because of food security and the extraordinary measures for rice are necessary to protect the income of poor farmers. 
It can be argued that ASEAN economic integration initiatives offer limited options for rice trade instead. While AMS has a clear obligation to reduce and remove tariffs, do away with quantitative restrictions, and identify non-tariff measures that obstruct trade for further actions, the special treatment is given to the rice sector remains. The Protocol to Give Special Consideration for Rice and Sugar which is part of the ASEAN Trade in Goods Agreement (ATIGA) (by ATIGA's Article 24) allows AMS to apply for a waiver on their liberalizing trade obligations about rice [3]. Based on these premises, this paper seeks to characterize the restrictive measures on rice trade by selected AMS, identify the problems emanating from those measures, and propose preliminary solutions.

\section{Methodology}

This paper will employ the usual method in legal research, namely doctrinal legal research. Such method analyses legal doctrines reflected in rules, principles, norms, interpretive guidelines and values and the instruments in which the doctrines are found can be cases, statutes, and rules [4]. The method can involve both domestic law and international law where the instruments mainly refer to treaties. This paper will also employ comparative law research as a method. Comparative law research allows similarities and differences between the laws of more than one jurisdiction or two or more legal systems to be detected [5].

As stated, only the laws of selected AMS will be analyzed. The selected AMS are Indonesia, Malaysia, Philippines, Thailand, and Vietnam. This is because as can be seen from Table 1, all the five countries are the leading rice exporters and importers in ASEAN. The laws of the AMS that are analyzed are:

(i) Indonesia

- Law Number 19 of 2013 on Farmers Protection and Empowerment;

b. the Regulation of the Minister of Agriculture of the Republic of Indonesia number 51/permentan/HK.310/4/2014 on the Recommendation of Export and Import of Certain Rice;

c. the Regulation of the Minister of Trade No. 103 / M-DAG / PER / 12/2015 on Provisions on the Export and Import of Rice promulgated on December 8, 2015;

(ii) Malaysia

a. the Customs (Prohibition of Imports) Order 2017;

b. the Control of Padi and Rice Act 1994 and its corresponding Regulations (particularly the Control of Padi and Rice (Licensing of Importers and Exporters) Regulations 1994);

(iii) the Philippines

a. Republic Act No. 2207 (An Act Prohibiting the Importation Of Rice and Corn and to Provide Penalties for the Violation Thereof);

b. Republic Act No. 663 (an Act to Develop and Improve the Rice and Corn Industries, to Stabilize the Price of Rice and to Promote the Social and Economic Conditions of the People Engaged in the Production of these Staple Foods);

(iv) Thailand

a. the Act Controlling the Importation and Exportation of Goods;

b. the Rice Trading Act 1946;

(v) Vietnam

a. Decree 109/2011/ND-CP 2011;

b. Decision 6139/QD-BCT 2013. 
Finally, the legal documents are analyzed against some pure statistical data which depict the performance of the selected AMS in rice trade. The data are encapsulated in Table 2 below. While the data in the table will be analyzed in Section 3 of this article, it is important to highlight from the very beginning that out of the five selected AMS, three members are net importers of rice and 2 are net exporters of rice. The net importers are Malaysia, Indonesia, and the Philippines, while the net exporters are Thailand and Vietnam. As will be seen below, the difference in such status may indicate a specific pattern in the regulatory system of each AMS.

The more basic statistical information is also needed on areas size and population size the selected AMS. This can be seen in Table 1 below:

Table 1. AREA AND POPULATION SIZE OF SELECTED AMS

\begin{tabular}{|l|l|l|}
\hline & $\begin{array}{l}\text { Area Size } \\
\text { (square km) }\end{array}$ & $\begin{array}{l}\text { Population } \\
\text { Size } \\
\text { (million - } \\
\text { 2011) }\end{array}$ \\
\hline $\begin{array}{l}\text { Indonesia } \\
\text { (Importer) }\end{array}$ & $1,904,569$ & 245.7 \\
\hline $\begin{array}{l}\text { Malaysia } \\
\text { (Importer) }\end{array}$ & 330,803 & 28.64 \\
\hline $\begin{array}{l}\text { Philippines } \\
\text { (Importer) }\end{array}$ & 300,000 & 95.28 \\
\hline $\begin{array}{l}\text { Thailand } \\
\text { (Exporter) }\end{array}$ & 513,320 & 67.53 \\
\hline $\begin{array}{l}\text { Vietnam } \\
\text { (Exporter) }\end{array}$ & 332,698 & 87.86 \\
\hline
\end{tabular}

\section{Findings}

\subsection{A Brief Description of AMS Restrictive Rice Measures}

Institutionally speaking, the surveyed laws of the AMS show the involvements of multiple agencies and ministries that oversee the regulation of importation and exportation of rice. As regards Indonesia, the licenses to import or export rice are issued by the Ministry of Trade but subject to the recommendations by the Ministry of Agriculture. That explains why the regulations issued by both ministries exist side by side. Malaysia takes a different approach: any matter restricting the importation or exportation of rice is merely mentioned in the Customs Orders which are in pursuance of the Malaysian Customs Act, but import licensing is under the authority of the Ministry of Agriculture. In Thailand, the Rice Trading Act 1946 is operated by both the Ministry of Commerce and the Interior Ministry, but the Act Controlling the Importation and Exportation of Goods is under the authority of the Ministry of Commerce. 
Substantively, all the AMS surveyed have laws that control production, marketing, and trading of rice. However, what the laws show is the close interaction between laws that regulate exportation and importation of rice and the laws that regulate domestic production and trading of rice. The laws impose floor price of rice on farmers and maximum price for consumers (so that both farmers and consumers are entitled to fair prices), specify the percentage of paddy rejects for rice grading, limit the right of farmers/traders to impose conditions of sales of rice, restrict the right of farmers to sell and deal with rice, restrict internal movement of rice, etc. Some provisions require permits/licenses for trading rice, and licenses for rice exportation and importation. Some provisions enable stockpiling of rice, price stabilization, and creation of an institution that is responsible for regulating the related activities. Many AMS justify these restrictions and limitations with food security.

However, there is a difference among the AMS surveyed regarding the prioritization of farmer interests over other interests, especially the business ones. Indonesia and the Philippines have legal provisions that make protecting the interests of rice farmers under the guidance in regulating rice trade.

In Indonesia, rice can only be imported if domestic rice production is insufficient and not produced domestically (the Regulation of the Minister of Agriculture of the Republic of Indonesia number 51/permentan/HK.310/4/2014). The precise legal intent of protecting domestic farmers could, in turn, support food security programs. Furthermore, Article 101, Law Number 19 of 2013 on Farmers Protection and Empowerment states that:

"Any Person who imports the Agricultural Commodities at the time of availability of domestic Agricultural Commodities is sufficient for consumption and government food reserves as referred to in Article 30 paragraph (1) shall be punished with imprisonment of 2 (two) years and a maximum fine of two billion rupiahs."

The criminal provisions are intended to protect farmers, especially from falling prices.

In the Philippines, the Republic Act No. 2207 makes it unlawful to import rice and corn into the Philippines unless there is an existing or imminent shortage in the local supply of rice and corn which is severe enough to constitute a national emergency. Importation of rice should be a situation of necessity in which only the President of the Philippines may authorize the importation of these commodities, through any government agency that he may designate. The National Economic Council will decide the quantities.

There is no such legal guidance in Malaysia and Thailand. Restrictions on importation (or exportation) of rice are merely stated in the "normal" Customs Order/Imports or Exports Regulations without express reference being made to the raison d' etre of protecting rice farmers. The legal position of the farmers can still be extracted from the laws that control production and internal movement of rice. Even so, the position is quite different between both countries.

The Thai Rice Trading Act 1946 specifies the areas where the restrictions and limitations apply (the areas are called rice-trading areas). The same law also exempts farmers who sell their cultivated rice from specific obligation, i.e., the obligation to obtain a rice trading permit (Section 11). In other words, Thai law targets rice traders more than the farmers themselves. The Malaysian Control of Padi and Rice Act 1994 does not focus on rice traders more than paddy farmers. Nor does it give special treatment to paddy farmers as opposed to rice traders as farmers are only allowed to sell paddy but they are not allowed to process and sell rice.

In all of the AMS surveyed State, trading entities play a vital role in the regulation of rice trade, particularly in Indonesia, Malaysia, and the Philippines (which are net importers of rice). The entities that have been entrusted with such role are the National Logistic Agency 
(BULOG) - Indonesia, Padiberas Nasional Berhad (BERNAS) - Malaysia and National Rice and Corn Corporation - the Philippines.

In Malaysia, only BERNAS is allowed to import rice subject to the license being issued by the Ministry of Agriculture. However, in the event of under-supply such license can be given to others on a case by case basis. It must be noted that Indonesia and the Philippines through their entrusting legislation (the Regulation of the Minister of Trade No. 103 / M-DAG / PER / 12/2015 on Provisions on the Export and Import of Rice (Indonesia) and Republic Act No. 663 (the Philippines)) specify the designated agency or body. In contrast, Malaysia's entrusting legislation (the Control of Padi and Rice Act 1994 and the Control of Padi and Rice (Licensing of Importers and Exporters) Regulations 1994) does not expressly mention BERNAS as the designated agency (the terms and conditions of license are also not clarified, unlike the legal provisions of Indonesia and the Philippines which detail out the conditions for importing rice).

In Indonesia, only BULOG is allowed to import rice subject to the issuance of a license by the Ministry of Trade upon recommendation from the Ministry of Agriculture. In Indonesia, private enterprises are not allowed to import rice unless in exceptional circumstances. However, for all the three AMS, the bodies that maintain the rice monopoly may not have the same status. Philippines's National Rice and Corn Corporation is a statutory body. BULOG of Indonesia is a Government agency. In contrast, Malaysia's BERNAS is supposed to replace the defunct Paddy and Rice Board (LPN) but engage widely in commercial activities and is partly owned by private individuals.

Finally, a different pattern is found in AMS, which are net exporters of rice (Thailand and Vietnam). In these countries, because of the conditions required for the exportation of rice, trade associations play a more active role in deciding on important matters such as determination of floor price and quantities of licenses. The associations include the Vietnam Food Association, Thai Rice Exporters Association, and Thai Rice Mills Association. However, restrictive measures on exports can still be evident. In Vietnam, stringent conditions have been imposed on rice exports - Decision 6139/QD-BTC of the Ministry of Industry requires exporters to export at least 10,000 tons of rice per year. Consequently, only a few oligopolistic state-owned enterprises have the capacity to export rice.

\subsection{The Restrictive Measures - How do they Fare?}

To address the above question, it will be useful to refer to Table 2 below:

TABLE 2. AMS PERFORMANCE IN RICE TRADE (the Year 2011)

\begin{tabular}{|l|l|l|l|l|}
\hline & $\begin{array}{l}\text { Total } \\
\text { Rice- } \\
\text { Planted } \\
\text { Land } \\
\text { (million } \\
\text { hectares) }\end{array}$ & $\begin{array}{l}\text { Total } \\
\text { Yields } \\
\text { (million } \\
\text { tons) }\end{array}$ & $\begin{array}{l}\text { Average } \\
\text { Yield } \\
\text { (ton per } \\
\text { hectare) }\end{array}$ & $\begin{array}{l}\text { Total } \\
\text { Consumption } \\
\text { (million tons) }\end{array}$ \\
\hline $\begin{array}{l}\text { Indonesia } \\
\text { (Importer) }\end{array}$ & 12.11 & 36.35 & 3 & 39.55 \\
\hline $\begin{array}{l}\text { Malaysia } \\
\text { (Importer) }\end{array}$ & 0.675 & 1.69 & 2.5 & 2.71 \\
\hline
\end{tabular}




\begin{tabular}{|l|l|l|l|l|}
\hline $\begin{array}{l}\text { Philippines } \\
\text { (Importer) }\end{array}$ & 4.56 & 10.64 & 2.33 & 12.39 \\
\hline $\begin{array}{l}\text { Thailand } \\
\text { (Exporter) }\end{array}$ & 11 & 20.48 & 1.86 & 10.37 \\
\hline $\begin{array}{l}\text { Vietnam } \\
\text { (Exporter) }\end{array}$ & 7.6 & 26.5 & 3.49 & 19.57 \\
\hline
\end{tabular}

Source: as in[6]

The table above shows that there are specific dimensions with regards to rice trade affecting the surveyed AMS. As mentioned in Section 2 of this Article, Table 2 creates two main categories among those AMS: importer and exporter AMS. Among the importer AMS which have the significant population (Indonesia has 245.7 million, and the Philippines has 95.28 million, as of 2011 - refer Table 1), prime importance is placed on the availability of locally produced rice. Restrictive measures can be aimed at ensuring that local producers can continue to feed the local population. The scenario is reflective of the rice trade laws in both countries which establish the protection of farmers' interests as a central factor in any decision to allow rice imports. Due to population and natural resource endowment, both countries have the potential to be net rice exporters in the future. There is already an announcement that Indonesia is ready to be a rice exporter [7].

Malaysia tells a different story. Malaysia has the smallest total of rice-planted land $(0.675$ million hectares), compared to Indonesia (12.11 million hectares) and the Philippines (4.56 million hectares). Note that the area size of Malaysia is larger than the Philippines. This may mean Malaysia is the least productive in rice farming with far smaller land cultivated with rice. Many factors have been cited as the reasons for Malaysia's lack of productivity in rice production. They include small and non-economical size holdings, lack of capital, lack of irrigation and drainage facilities, inappropriate cropping and intensities, inaccessibility to markets, information and technological innovations, as in[8] and [9].

However, Malaysia is 3rd after Vietnam and Indonesia in terms of efficiency, indicating that despite low productivity, the country's rice industry is efficient. Efficiency is measured in tonnes per hectare. Thus if one measures the yields from Malaysia's rice fields as per aggregate, Malaysia has surpassed the Philippines and Thailand.

Importation of rice is tightly controlled, and the right to import is awarded only to BERNAS despite special case-by-case arrangements to loosen the monopoly made by the Malaysian Government in 2015, as in [10]. The question that remains is whether the legal measures on rice trade enhance productivity in rice production in Malaysia. Looking at the factors that hinder rice productivity in Malaysia as in [8] and[9], restriction on importation may be essential to prevent further labor shortage as farmers find it less attractive to farm rice due to increasing costs and decline in prices. Restriction on imports may make it more difficult for imported rice to be in the market. However, factors affecting productivity are more about empowering the farmers, whereas the relevant Malaysian laws on rice trade do not focus too much on it compared to Indonesia and the Philippines.

The presence of individual elements within BERNAS may push the organization towards profit maximization. When it is not that profitable to export (due to falling world prices), to enhance the export capability of the farmers may not be a preferred option.

There can still be restrictions on exports from AMS which are already net exporters, and these countries are prepared to loosen output in their exports if the world price is too low. In 
Thailand, the Thai rice-pledging scheme, which was a policy by the former Thai Government to purchase rice from farmers above market price, had discouraged Thai farmers from exporting when the world price declined. This reduced Thailand's rice exports, as in [3].

Vietnam can be considered a success story in expanding rice exports. It does not directly restrict its rice exports, but it has an annual minimum tonnage condition for exports. In other words, producers must be able to export beyond a certain minimum quantity in order to be given the license to export. This has the effect of limiting the opportunities for smaller traders to export rice and also prevented traders/farmers from exporting high-quality rice due to failure to meet the tonnage condition, as in [11].

Here, the restrictive measures appear to be a response to problems brought about by price volatility of rice. There is a link between rice price volatility and food insecurity, as in [1]. However, empirical studies have shown that the likelihood of extreme price volatility affecting farmers and consumers is low, and it is imported, not exports, that constrain regional rice trade, as in [1]. If ASEAN is to increase regional rice trade in terms of exports, the increase in the supply of rice needs to find its destination and as more AMS are striving for the net exporter status, who is going to buy the rice at the right price? Similar trends in China, India, and Pakistan may push the world price of rice further downward, which is already in decline.

At the micro-level, the restrictive measures may not benefit poor farmers. The creation of a monopoly that controls not only trade but also the production of rice can harm farmers if the farmers' interests are not safeguarded by the law (this is evident in Malaysia). This may deprive farmers many rights, including the rights to seed and fertilizers, and the right to choose purchasers and suppliers. The plight of the farmers may have nothing do with the liberalization of the rice market.

Removing obstacles to farmers and traders may not necessarily reduce their income. It has been found that rice trade liberalization through imports can "increase domestic supply and stabilize prices" enhancing food security of the relevant countries, as in [12]. This, of course, can be controversial to AMS primarily when one argues that in situations of national emergency, where the national stockpiles will find their supplies from? Various proposals have been forwarded including to create regional stockpiles at the ASEAN level or even extraregional stockpiles to include China, India, and Pakistan into the equation, as in[1]. There should be more creative solutions to the problem. Reducing the restrictiveness of rice trade measures can create incentives to explore new techniques including to integrate the supply chain within ASEAN and beyond. Stockpiles should not stand idle.

The expansion of the rice industry, including enhancing exports in certain AMS like Malaysia may not be limited to its general form. The rice industry includes what is upstream and downstream of the rice product. Rationalizing the restrictive measure can target the opening of the downstream market which has higher added-value or the introduction of a niche product such as premium rice which is unique to specific regions (including the Sarawak Highlands). It can also nurture the development of downstream industries.

\section{Conclusion}

This article finds that all the selected AMS have restrictive measures on the rice trade, but each of them has measures which are different in nature and effect. This article finds some similarity between Indonesia and the Philippines, but the situation is different in Malaysia, although they are net importers of rice. The focus explains much of it by the two (Indonesia and the Philippines) countries in becoming future net exporters of rice. There is also the relation between income and labor factors and the difficulty of sustaining the rice industry in 
Malaysia. This paper also finds restrictive measures in net exporters of rice (Thailand and Vietnam). They do not merely curtail imports but also exports. What connects the dots is price volatility.

Price volatility in food commodities, including rice, is a global phenomenon. Thus there is a need for regional monitoring of restrictive measures on rice trade in ASEAN. However, considering the limited scope of ASEAN economic integration has vis-à-vis rice trade, some AMS (Thailand and Malaysia) will face more significant challenges from regional and international competition in the rice sector compared to the others (Indonesia, Philippines, and Vietnam). On how the restrictive measures should be shaped, it depends on the utility of the existing regional initiatives, including the "ASEAN Single Market and Production Base" (ASMPB) concept.

The concept envisages the free flow of goods, services, capital, and investment. The way forward should be to realize the ASEAN and Global Value Chains but within limits necessary for ensuring the food security and income distribution objectives are achieved. The AMS must ensure that this happens while recognizing that restrictive measures can easily be captured by political, unique, and business interests.

As such, the AMS must have firm control mechanisms at both national and ASEAN levels against elements that distort domestic rice markets. This points to a role that should be played by competition law and policy, something which future researchers need to examine.

\section{References}

[1] R. L. Clarete, L. Adriano, and A. Esteban, "Rice trade and price volatility: implications on ASEAN and global food security," in ADB Economics Working Paper Series No. 368, Manila: Asian Development Bank, 2013.

[2] A. J. Halimi, Perdagangan dan Perkapalan Melayu di Selat Melaka (Trade and Shipping by Malays in the Strait of Malacca). Kuala Lumpur: Dewan Bahasa dan Pustaka, 2006.

[3] R. L. Clarete, "No Title," in International Trade in Food Security: Exploring Collective Food Security in Asia, M. Ewing-Chow, Ed. Cheltenham: Edward Elgar, 2016.

[4] T. H. T and N. Duncan, "Defining and describing what we do: doctrinal legal research,” Deakin Law Rev., vol. 17, pp. 83-119, 2012.

[5] M. V. Hoecke, "Methodology of comparative legal research," in Law and Method, 2015, pp. 1-35.

[6] E. J. Wailes and E. C. Chavez, "ASEAN and the global rice situation and outlook," in $A D B$ Sustainable Development Working Paper Series No. 22, Manila: Asian Development Bank, 2012.

[7] A. Sulaiman, Self-Sufficiency in Rice Achieved, Indonesia to Become Rice Exporter? 2017.

[8] M. M. M. Najim, T. S. Lee, M. A. Haque, and M. E. M, "Sustainability of Rice Production: A Malaysian Perspective," J. Agric. Sci., vol. 3, pp. 1-12, 2007.

[9] M. A. M. Alias, "Productivity in Agriculture," in Land Development Digest 5, 1982.

[10] N. F. Yen, Has Halex ended rice import monopoly? 2015.

[11] Q. T. Nguyen and K. G. Nguyen, Rice exports: It is time for the "giants" to leave. 2015.

[12] A. Gulati and S. Narayanan, "Rice Trade Liberalisation and Poverty," Econ. Polit. Wkly., vol. 58, pp. 45-51, 2003. 
